\title{
Disturbed testicular descent in horses - principles, diagnosis and therapy
}

\author{
J.E. Cox \\ University of Liverpool, UK
}

\begin{abstract}
Summary
The author reviews testis descent in the horse, with particular reference to current theories of its mechanism and draws attention to problems that veterinary surgeons may have in diagnosing cryptorchidism in new-born foals. A section on post-natal growth of the testis draws attention to factors causing inguinal retention of testes. The diagnosis of cryptorchidism in adult horses is discussed, as is the genetics of the condition. Possibilities for non-surgical treatment are also discussed, but the author concludes that such treatment is unjustified. Some brief notes on cryptorchidectomy conclude the article.
\end{abstract}

Keywords: Horses, testis descent, cryptorchidism, diagnosis, treatment

\begin{abstract}
Maldescendus testis beim Pferd - Grundlagen, Diagnose und Therapie
Neben einer Übersicht zum Thema Hodenabstieg beim Pferd unter besonderer Berücksichtigung aktueller Theorien zu dessen Mechanismus wird das Problem der Diagnose eines Kryptorchismus beim neugeborenen Fohlen behandelt. Störungen in der postnatalen Wachstumsperiode des Hodens als Ursache einer inguinalen Hodenretention werden diskutiert, ebenso Ätiologie und Diagnose des Kryptorchismus beim erwachsenen Hengst. Methoden einer konservativen Behandlung werden angesprochen, vom Autor jedoch als unbefriedigend beurteilt. Auf die operative Entfernung eines kryptorchiden Hodens wird kurz eingegangen.
\end{abstract}

Schlüsselwörter: Hengst, Hodenabstieg, Kryptorchismus, Diagnose, Therapie

\section{Testis descent}

The most accurate description of testicular descent in the horse is that of Bergin, Gier, Marion and Coffman (1970). Although they hypothesised about the mechanism of descent, their ideas have been modified in recent years by work in other species.

The current theory (see Hutson et al., 1990) is that testosterone from the fetal gonad brings about maturation of spinal cord neurones whose peripheral fibres comprise part of the genito-femoral nerve. This nerve, like many other spinal nerves, passes through a foramen in the body wall.

The gubernaculum develops as a strand of mesenchymal jelly reaching from the caudal pole of the primitive gonad through this foramen to just below the pelvic blastema where the scrotum will eventually be. Maturation of the neurones is associated with thickening of the gubernaculum where it passes through the foramen which is thus dilated by this thickening, thus forming what we know as the inguinal canal - this dilation makes testis descent possible, but does not cause it. The testis migrates from its primitive position near the kidney to a position just inside the inguinal canal - the mechanisms involved are still somewhat obscure, probably involving Mullerian Inhibiting Substance and an element of differential growth.

In the horse this process nears completion round about 60 days of pregnancy and in species of comparable body size descent of the testes through the inguinal canal occurs soon afterwards. However, at this point in fetal development, the gonad of the horse undergoes such prodigious enlargement that inguinal passage is impossible (Cole et al., 1933).

By the last month of pregnancy, however, the testis has shrunk to between 5 and $10 \mathrm{~g}$ in weight and testis descent is possible. Even now, however, the process is difficult. In other species, the testis appear to pass through the canal quickly since in dissections of fetuses it is rare to find a testis actually in the inguinal canal. In late pregnancy equine fetuses, however, a sausage-shaped, distorted testis can often be found in the canal, indicating that the testis has to be deformed in order to achieve passage. It is now generally believed that inguinal passage in all species comes about as a result of fetal movements which increase abdominal pressure and, in effect, herniate the testis through the inguinal canal.

It is probably that the disproportionate growth of the fetal gonad is the cause of most cases of abdominal retention of testes in horses - failure of regression results in a testis which is simply too big to be pushed through the canal. A similar size problem probably explains why most testes with teratomas (which develop during fetal life) fail to descend (see Willis and Rudduck, 1943).

In the neo-natal foal, therefore, the testis and the structures associated with its descent, particularly the swollen gubernaculum, have only just reached the inguinal region. Palpation of any colt foal in this early period will reveal structures in the inguinal region, even if the testis has failed to descend through the canal. This fact has given rise to the 
common misapprehension that all foals are born with two testes through the canal and that abdominal cryptorchidism develops later in life when one or both testes return to the abdomen.

\section{Post-natal growth of the testis}

Although the testis grows after birth such growth is not isometric. A number of authors have noted that the testes of ponies at six months of age have rarely grown significantly in size and at one year of age are only about twice their size at birth whereas the horse itself has at least quadrupled in weight (Nishikawa, 1959; Arthur and Allen, 1972; Glassneck, 1978; Cox, 1982). The relatively small size of the testis in the foal and young yearling can make palpation difficult since small testes tend not to reach the scrotum.

Even during the second summer of life, testis growth in the slow maturing pony is relatively retarded and it is not until spermatogenesis begins in earnest in the autumn or during the animal's second winter that the testis grows sufficiently to reach the scrotum and occupy it fully.

Collingsworth (1996) has observed a month to six week delay in maturation of the right testis in comparison with the left in normal Welsh Ponies. Sometimes this delay is extreme and is characterised by inguinal retention (see Cox, Edwards and Neal., 1979). In this breed, however, probably as in others, this retention is only temporary and by autumn of the third year of the animal's life (ie when it is a two-yearold), growth has occurred and a second testis is in the scrotum. This testis may be noticeably smaller than its partner and veterinary surgeons examining stallions at this age for licensing or registration purposes may have a difficult decision to make. There is a need for quantitative guidelines on what constitutes normality.

Post natal growth of the testis is influenced by a number of factors, including seasonal influences mediated by day length and there is still much to discover about the interaction of growth and photoperiod.

One last comment on testis growth. It must be recognised that a testis may return to the inguinal region if it undergoes shrinkage as result of pathological change. The author has met cases where testis shrinkage resulted in return of a testis to the inguinal region - one was brought about by strongyle larval migration damaging the blood supply and another by orchitis; in a third case the vascular cord of an abdominal testis was found to have undergone torsion and the testis shrank to a finger nail size - presumably the same thing could happen to a scrotal testis.

\section{Diagnosis of cryptorchidism}

The diagnosis of cryptorchidism begins with careful palpation of the inguinal region in a cooperative horse - the superficial inguinal ring can be palpated in such a horse.

Direct ultrasound of the inguinal region to determine whether an inguinally-retained testis is present has been advocated. Rectal palpation has also been advocated, without ultrasound (O'Connor, 1971) or with it, but the author believes that the procedure does not justify the risk - if the animal has a visible testis, it is likely to need surgery and if it does not, a blood test (see below) will tell whether surgery is required or not.

If there is no scrotal testis present, blood can be examined for the presence of either testosterone or, in the horse which is at least three years old, oestrone sulphate. The accuracy of these tests in the author's hands has been described (Cox et al., 1986). In some circumstances, faeces may be used instead of blood (Palme et al., 1998). However, it is important that the laboratory undertaking the measurement of either hormone is familiar with handling equine samples testosterone concentrations in horses are lower than in any other species and the oestrone sulphate assays used for pregnancy confirmation in mares may not always give accurate results for male horses.

\section{Genetics}

There is considerable debate as to whether cryptorchidism is inherited or not. It is probable that the situation is similar to that observed in goats (Lush et al., 1930) in which cases appear spontaneously as well as in lines of animals. If this is also the case in the horse, one need not expect every colt foal (or even a large proportion) sired by a cryptorchid stallion to be a cryptorchid. (See also Leipold et al., 1986, for some observations on stallions.) It has been argued that cryptorchidism in the pig is multi-factorial (Mikami et al., 1979) and these authors stated that individual selection remained the most practical approach to minimising the prevalence of cryptorchidism.

A wise approach would be to avoid breeding from a cryptorchid stallion and this is the approach most breed societies take. However, in rare breeds or in the case of a really outstanding animal, an exception may be justified - Hofmeyr (1968) in another connection has pointed out that no animal is absolutely perfect and that breeding decisions often involve compromises.

\section{Treatment}

It is widely regarded as unethical to provide a cryptorchid animal with a prosthetic testis as to do so is an attempt to deceive others of the true nature of the animal.

The manufacturers' literature often recommends the use of human Chorionic Gonadotrophin (hCG) as a treatment for testicular retention. However, veterinarians should be aware that even a single injection of hCG produces testicular oedema as a result of increased capillary permeability and the initial increase in size of a testis after hCG treatment is largely due to this, not to normal growth. A testis which has been retained in the inguinal region will undoubtedly descend as it enlarges, but in the author's view, most of those which descend in apparent response to hCG would have 
descended in time anyway. Once gubernacular regression has occurred shortly after birth, the inguinal canal is no longer dilated and it is thereafter impossible for an abdominal testis to descend.

There is also, in the author's opinion, no justification for surgical induction of descent in horses. This procedure is carried out in children, partly for aesthetic and psychological reasons and partly because it is recognised that retained testes have a higher rate of tumour formation in later life than those which have descended. Where it is attempted in children, it is usually now attempted well before puberty so as to give the best chance of normal spermatogenesis after puberty.

\section{Cryptorchidectomy}

Surgical removal of cryptorchid testes requires careful surgical exploration of the inguinal region under general anaesthesia to remove any testis retained in this area. Abdominal testes may be removed either by traction on the remains of the gubernaculum in the inguinal region Naldez et al., 1979), by paramedian laparotomy (Cox, Edwards and Neal., 1975) or with the aid of laparoscopy (see Fischer, 1997).

\section{Literature}

Arthur, GH and Allen, WE (1972): Clinical observations on reproduction in a pony stud. Equine Veterinary Journal 4, 109-117.

Bergin, WG; Gier, HT; Marion, GB and Coffman, JR (1970): A developmental concept of equine cryptorchidism. Biology of Reproduction 3, 8292.

Cole, HH; Hart, GH; Lyons, WR and Catchpole, HR (1933): The development and hormonal content of fetal horse gonads. Anatomical Record 56, 275-289.

Collier, MA (1980): Equine cryptorchidectomy: surgical considerations and approaches. Modern Veterinary Practice 61, 511-517.

Collingsworth, MGR (1996): Personal communication.

Cox, JE (1982): Factors affecting testis weight in normal and cryptorchid horses. Journal of Reproduction and Fertility Supplement 32, 129-134.

Cox, JE; Edwards, GB and Neal, PA (1975): Supra-pubic paramedian laparotomy for abdominal cryptorchidism in the horse. Veterinary Record 97, 428-432.

Cox, JE; Edwards, GB and Neal, PA (1979): An analysis of 500 cases of equine cryptorchidism. Equine Veterinary Journal 11, 113-116.
Cox, J E; Redhead, PH and Dawson, FE (1986): A comparison of the measurement of plasma testosterone and plasma oestrogens for the diagnosis of cryptorchidism in the horse. Equine Veterinary Journal 18, 179-182.

Fischer, AT (1997): Laparoscopic management of the cryptorchid horse. Equine Veterinary Education 9, 242-245.

Glassneck, HW (1978): Histometrische Untersuchungen über die Entwicklung des Pferdehoden zwischen 1. und 18. Lebensmonat. Tierärtzliche Hochschule, Hannover.

Hofmeyr, CFB (1968): Surgery of bovine impotentia coeundi VI. Journal of the South African Veterinary Medical Association 39, 3-16.

Hutson, JM; Williams, MPL; Fallat, ME and Attah, A (1990): Testicular descent: new insights into its hormonal control. Oxford Reviews of Reproductive Biology 12, 1-56.

Leipold, HW; De Bowes, RM; Bennett, S; Cox, JH and Clen M. F. (1986): Cryptorchidism in the horse; genetic implications. Proceedings of the Annual Convention of the American Association of Equine Practitioners 31, 579-590.

Lush, JL; Jones, JM and Dameron, WH (1930): The inheritance of cryptorchidism in goats. Bulletin of the Texas Agricultural Experimental Station 407

Mikami, H and Fredeen, HT (1979): A genetic study of cryptorchidism and scrotal hernia in pigs. Canadian Journal of Genetics and Cytology 21, 9-19.

Nishikawa, Y (1959): Studies on reproduction in horses. Japan Racing Association, Tokyo.

O'Connor, JP (1971): Rectal examination of the cryptorchid horse. Irish Veterinary Journal 25, 129-131.

Palme, R; Scherzer, S; Stollar, K; Nagy, P; Szenci and O; Mostl, E (1998): Hormonal diagnosis of equine cryptorchidism. Wiener Tierärtzliche Monatsschrift 85, 188-191.

Willis, RA and Rudduck, HB (1943): Testicular teratoma in horses. Journal of Comparative Pathology and Bacteriology 55, 165-171.

Dr. JE Cox, BSC, BVetMed, PhD, FRCVS

Senior Lecturer in Equine Reproduction

Division of Equine Studies

Department of Veterinary Clinical Science and Animal Husbandry University of Liverpool

Leahurst

Neston

SOUTH WIRRAL CH64 TTE,

UK

Phone (044) 1517946041

Facsimile (044) 1517946034

email coxjohne@liverpool.ac.uk 